\title{
The regulation of $\mathrm{CD} 4^{+} \mathrm{T}$ cell responses during protozoan infections
}

\section{Christian R. Engwerda ${ }^{1}$, Susanna S. Ng ${ }^{1,2}$ and Patrick T. Bunn ${ }^{1,3}$}

1 QIMR Berghofer Medical Research Institute, Brisbane, QLD, Australia

2 School of Natural Sciences, Griffith University, Nathan, QLD, Australia

${ }^{3}$ Institute of Glycomics, Griffith University, Gold Coast, OLD, Australia

\section{Edited by:}

Dragana Jankovic, National Institutes of Health, USA

\section{Reviewed by:}

Sid P. Kerkar, National Institutes of Health, USA

Kevin Couper, University of

Manchester, UK

*Correspondence:

Christian R. Engwerda, QIMR Berghofer Medical Research Institute, 300 Herston Road, Herston, QLD 4005, Australia

e-mail: chrise@qimr.edu.au
$\mathrm{CD}^{+} \mathrm{T}$ cells are critical for defense against protozoan parasites. Intracellular protozoan parasite infections generally require the development of a Th1 cell response, characterized by the production of IFN $\gamma$ and TNF that are critical for the generation of microbicidal molecules by phagocytes, as well as the expression of cytokines and cell surface molecules needed to generate cytolytic $\mathrm{CD}^{+} \mathrm{T}$ cells that can recognize and kill infected host cells. Over the past 25 years, much has been learnt about the molecular and cellular components necessary for the generation of Th1 cell responses, and it has become clear that these responses need to be tightly controlled to prevent disease. However, our understanding of the immunoregulatory mechanisms activated during infection is still not complete. Furthermore, it is apparent that although these mechanisms are critical to prevent inflammation, they can also promote parasite persistence and development of disease. Here, we review how $\mathrm{CD}^{+} \mathrm{T}$ cells are controlled during protozoan infections and how these regulatory mechanisms can influence parasite growth and disease outcome.

Keywords: protozoan parasites, Th1 cells, IL-10, IL-27, CD4 ${ }^{+} \mathrm{T}$ cells, immune regulation

\section{INTRODUCTION}

Mammalian immune systems have evolved to recognize and control pathogens. This is achieved by the coordinated actions of innate and adaptive immune mechanisms [reviewed in Ref. $(1,2)$ ]. $\mathrm{CD}^{+} \mathrm{T}$ cells play key roles in coordinating immune responses by producing molecules critical for the production of high affinity antibodies by $\mathrm{B}$ cells and promoting the production of mucous and tissue repair mechanisms. They also help to fully activate $\mathrm{CD}^{+} \mathrm{T}$ cells so they can kill infected and transformed cells, and assist innate immune cells to recognize and control pathogens and tumors. $\mathrm{CD}^{+} \mathrm{T}$ cells play critical roles in both the generation of anti-parasitic immunity and immune surveillance during concomitant immunity, which is associated with many parasitic infections (3).

\section{REGULATION OF T CELL RESPONSES}

The help provided by $\mathrm{CD} 4^{+} \mathrm{T}$ cells for various immune activities includes the production of potent pro-inflammatory cytokines such as TNF, IFN $\gamma$, and IL-17, and as such, CD4 ${ }^{+}$T cell responses need to be tightly regulated so they themselves do not cause tissue damage. The pathogenesis of autoimmune diseases often involves aberrant $\mathrm{CD}^{+} \mathrm{T}$ cell responses in tissue sites such as the central nervous system, pancreas, and brain. Therefore, mammals have evolved multiple ways to control the pathogenic potential of CD4 ${ }^{+} \mathrm{T}$ cells [reviewed in Ref. (4)]. These include indoleamine 2,3-dioxygenase (IDO)-catalyzed tryptophan metabolism by phagocytic cells (5), leading to immune cell stress and activation of the general controlled non-repressed 2 (GCN2) kinase pathway (6) and/or cytotoxic and regulatory effects on $\mathrm{T}$ cells caused by the catabolites from the associated kynurenine metabolism pathway (7). In addition, the production of regulatory cytokines, such as IL-10 and TGF $\beta$, by innate immune cells in response to pathogen-derived molecules can suppress both developing and established T cell responses (8-10), as can IL-10 produced by certain B cell subsets (11). Dendritic cells (DCs) can be an important source of regulatory cytokines in experimental models of leishmaniasis and malaria. In addition, over the course of these infections, DCs reduce levels of CD11c, increase expression of CD45RB, and promote the generation of $\mathrm{T}$ cell IL-10 production (12-14). Thus, the development of regulatory DC subsets that have a major influence on $\mathrm{T}$ cell responses is a feature of established protozoan infections. More recently, specialized monocytes and macrophage subsets have been identified that can modulate localized $\mathrm{T}$ cell responses during protozoan infections [reviewed in Ref. (15)]. Classically activated (M1) macrophages produce pro-inflammatory molecules, such as TNF and L-arginine-dependent nitric oxide, while alternatively activated (M2) macrophages use arginase 1 to convert L-arginine to polyamines, which along with production of IL-10 and TGF $\beta$, enable this cell subset to suppress inflammation [reviewed in Ref. (16)]. Inflammatory monocytes have been reported to promote Th1 cell activity in mice infected with Leishmania major (17), L. donovani (18), and Trypanasoma brucei $(19,20)$, but with pathological consequences in the latter model that were reversed by administration of IL-10 (20). In contrast, the products from M2 macrophages suppressed lesional CD4 ${ }^{+} \mathrm{T}$ cell proliferation and IFN $\gamma$ production in mice infected with $L$. major (21), while $T$. gondii can actively promote the arginase 1 pathway in macrophages to enhance pathogen survival (22). Thus, macrophages play important roles in conditioning local tissue 
environments and determining the direction and effectiveness of $\mathrm{T}$ cell responses during protozoan infections. However, regulatory mechanisms increasingly recognized as being paramount for preventing $\mathrm{T}$ cell-mediated disease, and therefore, the main subject of this review, involve specialized sub-populations of $\mathrm{CD}^{+}$ $\mathrm{T}$ cells themselves capable of inhibiting immune responses and suppressing inflammation.

\section{REGULATORY T CELLS}

Regulatory $\mathrm{T}$ cells can be broadly divided into two types. First, natural regulatory $\mathrm{T}$ (Treg) cells are $\mathrm{CD} 4^{+} \mathrm{T}$ cells produced in the thymus and express the transcription factor FoxP3 that is critical for their suppressive functions $(23,24)$. Second, inducible regulatory $\mathrm{T}$ cells emerge from the thymus as conventional $\mathrm{T}$ cells, but develop regulatory functions in the periphery following exposure to appropriate inflammatory stimulation. These include IL-10-producing Th1 ( $\operatorname{Tr} 1)$ cells (25), TGF $\beta$-producing CD4 ${ }^{+} \mathrm{T}$ (Th3) cells (26), and conventional $\mathrm{CD}^{+}{ }^{+} \mathrm{T}$ cells that have converted to FoxP3-positive cells in peripheral tissues (27). Under homeostatic conditions, Treg cells limit potentially self-reactive $\mathrm{T}$ cell responses, thus preventing autoimmunity (23). However, they can also impair effective pathogen clearance, while trying to prevent immune-mediated tissue damage during infection. The molecular mechanisms by which Treg cells perform these functions are incompletely understood, but involve production of cytokines such as IL-10, TGF $\beta$, and IL-35, the expression of the negative regulatory molecule cytotoxic $\mathrm{T}$ lymphocyte-associated antigen 4 (CTLA-4) and the generation of adenosine and cyclic AMP [reviewed in Ref. (28)]. In addition, their expression of high affinity IL-2 receptor allows them to deprive conventional $\mathrm{T}$ cells of this critical growth factor and thereby induce them to undergo apoptosis (29). Thus, Treg cells may act directly upon conventional T cells or via accessory cells such as antigen presenting cells (APCs) to limit T cell activity. An emerging paradigm is that Treg cells adapt to particular inflammatory conditions in order to regulate specific $\mathrm{CD} 4^{+} \mathrm{T}$ cell responses by the generation and use of shared transcription factors to mimic certain aspects of $\mathrm{T}$ cell behavior, such as tissue homing, survival, and cytokine production. For example, STAT3, T-bet, IRF-4, and Bcl6 are required for Th17, Th1, Th2, and follicular helper T (Tfh) cell differentiation, respectively, as well as by the Treg cells that control the actions of these specific $\mathrm{CD}^{+} \mathrm{T}$ cell subsets (3034). For example, in mice orally infected with $T$. gondii, IL-27 promotes the expression of CXCR3 on Treg cells that enables these cells to regulate Th1 cell-mediated immunity, as well as prevent infection-induced pathology at mucosal sites (35). However, Treg cells can block the generation of effective parasite-specific $\mathrm{T}$ cell responses in specific tissues. For example, Treg cell depletion with anti-CD25 mAb in mice infected with L. major dramatically enhanced anti-parasitic immunity (36), while adoptive transfer of antigen-specific Treg cells in the same model promoted parasite growth (37). In addition, depletion of Treg cells with an anti-CD25 $\mathrm{mAb}$ protects mice from lethal Plasmodium yoelii infection by enabling the generation of a potent anti-parasitic $\mathrm{T}$ cell response (38). Similarly, the removal of Treg cells from peripheral blood mononuclear cells isolated from humans infected with $P$. falciparum enhanced $\mathrm{T}$ cell proliferation and $\mathrm{CD} 4^{+} \mathrm{T}$ cell IFN $\gamma$ production in response to stimulation with parasite antigens (39). However, the importance of Treg cells in several protozoan infections has been questioned because of the potential "off-target" effects of the anti-CD25 mAbs used in many studies (40). For example, several groups reported significant changes in immune responses and disease outcome in mice infected with $P$. berghei ANKA (41-43), but subsequent experiments in this model, where Treg cells could be specifically depleted with diphtheria toxin via cell-specific expression of a simian diphtheria toxin receptor (44), showed little impact of Treg cells on disease outcome and associated $\mathrm{T}$ cell responses $(45,46)$. Thus, the roles of Treg cells in protozoan infections will require further studies before their impact on anti-parasitic immune responses can be fully appreciated.

The secretion of IL-10 by conventional CD4 ${ }^{+} \mathrm{T}$ cells can potently suppress inflammation and tissue damage $(47,48)$. Initially, IL-10 production was identified in Th2 cells (49), but has since been described in Th1 (50-52) and Th17 (53) cell populations. Thus, $\mathrm{CD}^{+} \mathrm{T}$ cell-derived IL-10 production is emerging as an important mechanism of auto-regulation, whereby IL-10 can both directly suppress $\mathrm{T}$ cell activities, as well as upstream activation pathways initiated by APCs [reviewed in Ref. (48)]. These IL-10-producing Th1 cells were identified in mice infected with T. gondii (54) and L. major (55). In the T. gondii infection model, these cells did not impact upon control of parasite growth, but were critical for limiting pathology $(54,56)$, while in mice infected with L. major, IL-10-producing Th1 cells promoted the establishment and maintenance of chronic infection (55). Similar observations have also been made in mouse models of Plasmodium infection $(57,58), T$. cruzi $(59,60)$, and T. brucei (61) infections. Importantly, these IL-10-producing Th1 cells have been identified in humans with visceral leishmaniasis caused by L. donovani (62) and African children with P. falciparum malaria $(63,64)$. Although IL-10 has been clearly shown to suppress $\mathrm{CD} 4^{+} \mathrm{T}$ cell activation in humans infected with $L$. donovani $(65)$ and $P$. falciparum $(63,66)$, it is not yet clear how much of this activity can be attributed to the IL-10-producing Th1 cells. Significantly, the prevalence of IL-10-producing Th1 cells in Gambian children with asymptomatic malaria was greater than in children with severe disease, indicating that these cells may protect against damaging inflammation during acute malaria (67). However, antigen-specific IL-10-producing Th1 cells were found in cord blood of babies whose mothers had malaria during pregnancy (66), suggesting that these cells might be able to influence anti-parasitic immunity from very early in life. Hence, the kinetics of the emergence of IL-10-producing Th1 cells during malaria may be critical in determining the impact they have on the outcome of infection.

\section{THE ROLES OF IL-10 IN PROTOZOAN INFECTIONS}

IL-10 is one of the most potent regulatory cytokines produced by leukocytes in response to inflammatory signals (68). The importance of IL-10 for regulating immunity is highlighted by the observation that IL-10 deficiency or blockade causes the early development of colitis in mice (69). However, as described above, many protozoan parasites, such as those that cause toxoplasmosis, malaria, trypanosomiasis, and leishmaniasis (54, 55, 59-61, 
$70,71)$, have evolved to exploit the functions of IL-10 to inhibit anti-microbial mechanisms and allow the establishment of chronic infection. In fact, the generation of IL-10-producing $\mathrm{T}$ cells following vaccination with protozoan antigen can be a robust predictor of vaccine failure (28). One proposed mechanisms for IL-10-mediated immune suppression is the promotion of $\mathrm{T}$ cell exhaustion. The PD-1 pathway plays an important role in $\mathrm{T}$ cell exhaustion during all of the chronic infections mentioned above, and there is strong evidence that IL-10 plays a key role in regulating the expression of the PD-1 ligands (PD-L1 and PD-L2) on APCs [reviewed in Ref. (72)]. Several other molecules known to be involved in promoting $\mathrm{T}$ cell exhaustion, such as Tim-3 and Lag3, have also been linked with IL-10 expression $(73,74)$, but their precise relationships are not known. IL-10 produced by macrophages can also inhibit the differentiation of surrounding cells into classically activated macrophages that are required for the production of inflammatory cytokines and metabolites required to kill many intracellular pathogens (75). It can also suppress inflammatory cytokine production by $\mathrm{T}$ cells and inhibits antigen presentation by APC [reviewed in Ref. (76)]. Thus, IL-10 can suppress host immune responses during infection by multiple mechanisms.

\section{REGULATION OF IL-10 PRODUCTION BY CD4+ T CELLS}

An important approach to understanding how IL-10 production might be modulated for therapeutic advantage or to improve vaccination is to gain a better insight into the transcriptional regulation and the signaling pathways involved in IL-10 production and establishing whether they differ between cell types and in various tissue locations. IL-27 has emerged as an important growth and differentiation factor for IL-10-producing Th1 cells $(53,77,78)$. It is thought to primarily be a product of macrophages and DCs (79), and drives the production of IL- 21 by CD4 ${ }^{+} \mathrm{T}$ cells, which in turn, acts as an autocrine growth factor for IL-10producing Th1 cells $(80,81)$. IL-27 is a heterodimeric cytokine composed of IL-27p28 and EBI3 that signals via a receptor complex comprising a unique IL-27 receptor alpha chain (IL-27R $\alpha$ ) and gp130 $(82,83)$, a common receptor used by several cytokines including IL-6 $(84,85)$. IL-27 promotes these activities via the transcription factors STAT1 and STAT3 (53), and by inducing the expression of the transcription factors c-Maf (80) and aryl hydrocarbon receptor (AhR) (86), which then physically associate and transactivate the IL-10 and IL-21 gene promoters (80, 86, 87). Interactions between glucocorticoid-induced TNFR-related (GITR) protein and GITR ligand can also stimulate IL-27 production (88), which can induce expression of inducible $\mathrm{T}$ cell costimulator (ICOS) on IL-10-producing Th1 cells to enhance IL-27-mediated expansion of these cells (80). Interestingly, IL$27 \mathrm{p} 28$ can also function as a natural antagonist of gp 130-mediated cytokine signaling, and thereby inhibit IL-6-mediated inflammatory pathways (89). The importance of IL-27 for the generation of IL-10-producing Th1 cells has now been reported in mouse models of malaria $(58,90)$, leishamaniasis $(91)$, and toxoplasma (53), although, surprisingly, the generation of these cells was independent of IL-21 in mice infected with P. chabaudi (58). It should also be noted that IL-27 has IL-10-independent regulatory functions in mice infected with P. berghei NK65 (90), thus emphasizing the complexity of IL-27-mediated immune regulation during protozoan infections. IL-27 produced by CD14 positive monocytes was also reported to be associated increased numbers of IL-10producing Th1 cells in blood from visceral leishmaniasis patients (92). Thus, there is substantial evidence for IL-27 being a critical factor in the generation of IL-10-producing Th1 cells during protozoan infections.

In other studies, the transcriptional repressor B lymphocyteinduced maturation protein 1 (Blimp1; encoded by the Prdm1 gene) was found to be expressed by a subset of Treg cells and played an essential role in their production of IL-10 (93). Recently, Blimp1 was implicated in IL-10 production by Th1 cells (94), and shown to be important for the generation of these cells in mice infected with $T$. gondii (95). IL-27 and T cell receptor signaling were found to promote the expression of the transcription factor Erg2, which was required for Lag3 expression and production of IL-10 by conventional CD4 ${ }^{+} \mathrm{T}$ cells (96). Subsequently, IL27-dependent Egr2 expression was reported to be critical for the induction of Blimp1 and generation of IL-10-producing Th1 cells (94). Interestingly, only STAT3-deficiency impacted upon IL-27dependent Egr2 expression, while both STAT1 and STAT3 were required for IL-10 production by Th1 cells. Thus, a model for IL10 production by Th1 cells is emerging (Figure 1). Furthermore, cellular pathways such as the Notch-Jagged axis in plasmacytoid DCs promote CD4 ${ }^{+}$T cell IL-10 production (97), but their roles in protozoan infections have yet to be investigated. Thus, there are still many gaps to be filled, and importantly, we need to clearly define the signaling and transcriptional pathways that are activated during protozoan infections. In particular, there is a clear gap in our knowledge regarding differences in the regulation and maintenance of IL-10 production by Th1 cells in secondary lymphoid organs and peripheral tissue sites. This information is important if we want to target these regulators to selectively modulate IL-10 activity during parasitic disease. In the broader context of immune regulation, we need to establish whether the IL-10-producing Th1 cells are a distinct $\mathrm{T}$ cell subset capable of dynamic and sustained regulatory function or whether they represent exhausted $\mathrm{T}$ cells, as suggested by their expression of molecules such as PD-1 and Lag3. In the former, we can develop ways to manipulate them for therapeutic advantage (for example in inflammatory diseases) or transiently block their function, as might be required for effective vaccination. However, if they represent a terminally differentiated state, then different approaches may have to be devised to either promote or inhibit their development.

\section{OTHER MECHANISMS OF Th1 CELL REGULATION DURING PROTOZOAN INFECTIONS}

Although IL-10 is a potent regulator of Th1 cell responses, there is likely to be multiple mechanisms to control such potentially damaging inflammatory responses. Type I IFNs have recently emerged as import immune regulators during parasitic infections. They are produced by most cell types and play critical roles in anti-viral immunity $(98,99)$, but several studies have identified this family of cytokines as important determinants of disease outcome in protozoan infection. However, these effects depend on the virulence of the parasite and the stage of infection. For example, in 


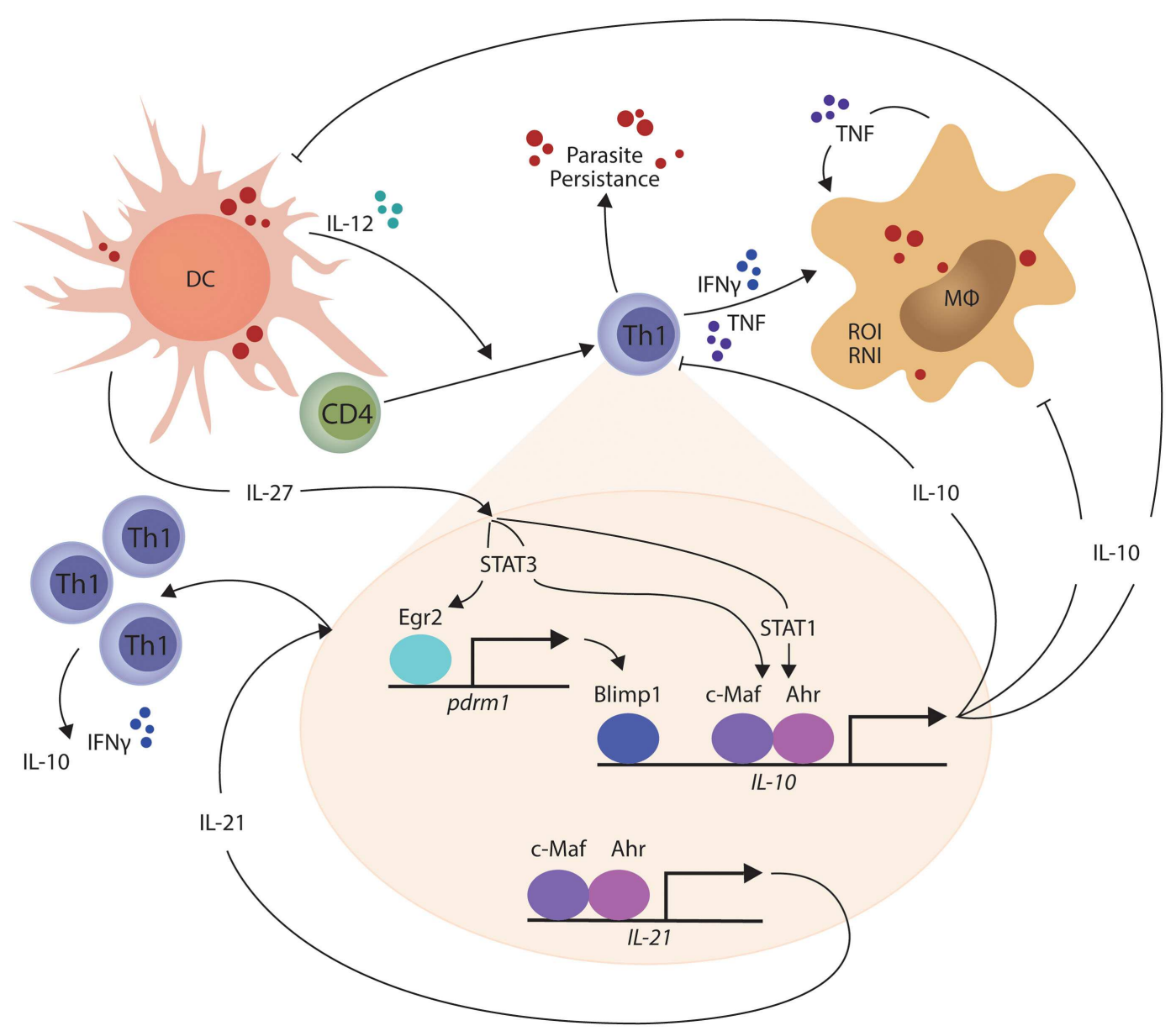

FIGURE 1 | IL-27-mediated generation of IL-10-producing Th1 cells is shown. In the presence of persistent parasite antigen exposure, IL-27 from macrophages and dendritic cells (DCs) stimulates STAT1 and STAT3-dependent transcription of c-Maf and aryl hydrocarbon receptor (AhR) in Th1 cells, which then physically associate and bind the IL-10 and IL-21 gene promoters to drive gene transcription. IL-27 and T cell receptor signaling also combine to promote the expression of the transcription factor
Erg2, which is critical for the induction of Blimp1 and generation of IL-10-producing Th1 cells in a STAT3-dependent manner. IL-21 acts as an autocrine growth factor for IL-10-producing Th1 cells, while the IL-10 produced by these cells can suppress the inflammatory functions of Th1 cells and phagocytes, as well as the antigen presenting capacity of DCs, macrophages (MØ), and monocytes (MO). The small red circles represent protozoan parasites and associated antigens. mice lacking type I IFN receptor, early control of T. brucei was impaired, but it appeared that IFN $\gamma$ production later in infection was suppressed by type I IFN signaling pathways (100). In contrast, early control of a high dose T. cruzi infection was enhanced in type I IFN receptor-deficient mice and this was associated with increased IFN $\gamma$ production, but not when a lower parasite dose was used (101). In liver stage $P$. berghei ANKA infection, parasite RNA triggers a type I IFN transcriptional program in hepatocytes that enhances innate immune responses in hepatic myeloid cells to control liver parasite load (102). In contrast, in mice infected with $P$. berghei ANKA blood-stage parasites, type I IFNs promoted susceptibility to severe disease $(103,104)$ by suppressing Th1 cell development (103) indirectly through inhibition of $\mathrm{CD}^{-} \mathrm{DC}$ function (105). Interestingly, this latter effect of type I IFN on DC function was also associated with reduced IL-10 mRNA accumulation in $\mathrm{CD}^{-}$DCs that lacked type I IFN receptor, potentially linking infection-induced IL-10 production with Th1 regulation once again (Figure 2).

TGF $\beta$ has also emerged as an important regulatory cytokine controlling Th1 responses during protozoan infections [reviewed in Ref. (106)]. In mice, susceptibility to lethal P. berghei ANKA infection correlated with reduced TGF $\beta$ levels (107), while high levels of TGF $\beta$ in malaria patients was associated with increased parasite growth. In mice infected with $T$. gondii, TGF $\beta$ produced by gut intraepithelial $\mathrm{CD}^{+}{ }^{+} \mathrm{T}$ cells was critical for controlling inflammation and gut pathology (108), thus supporting a key role for this cytokine in regulating inflammation during protozoan infections. In both malaria and toxoplasma, it is likely that TGF $\beta$ acts by suppressing $\mathrm{T}$ cell activation and promoting Treg cell functions (109). However, this is yet to be formally demonstrated and there still remains much to learn about the functions of TGF $\beta$ during infection. 


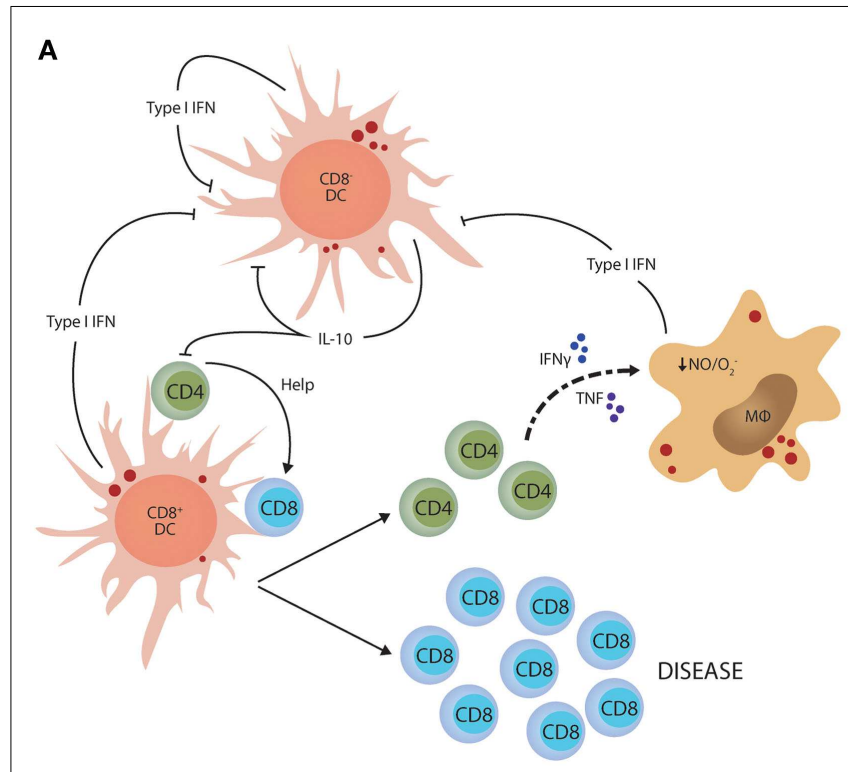

FIGURE 2 | Type I IFN-mediated suppression of Th1 cell activation

(A) Parasite molecules stimulate type I IFN production by different dendritic cell (DC) subsets and macrophages (MØ). This family of cytokines feedback on these innate immune cells and suppress their capacity to activate $\mathrm{CD} 4^{+} \mathrm{T}$ cells. In experimental malaria caused by Plasmodium berghei ANKA, this

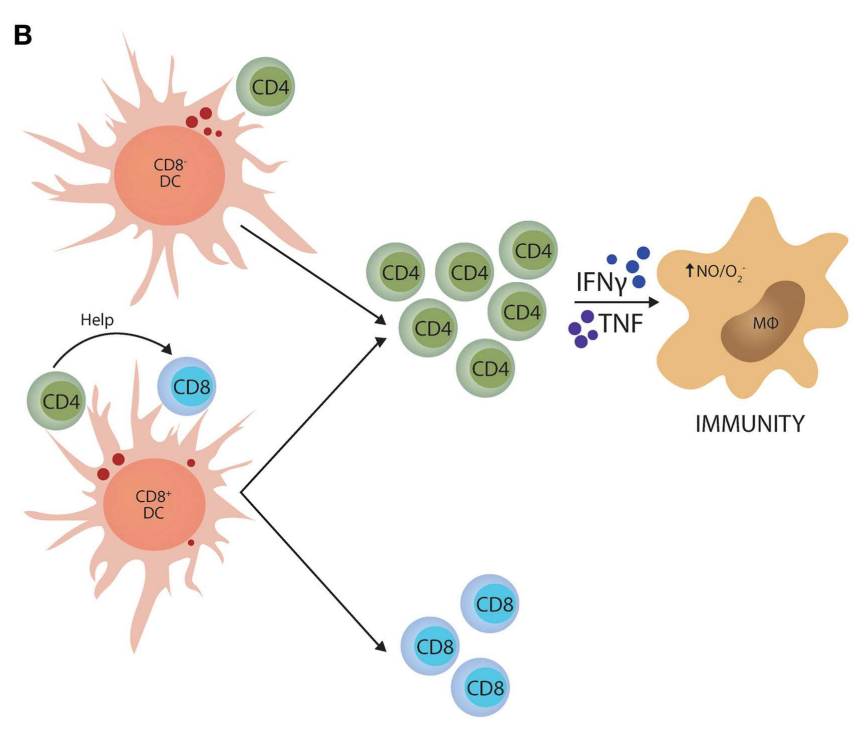

effect is primarily directed toward the CD8- DC subset and stimulates IL-10 production. (B) In this model, blockade of type I IFN signaling dramatically enhances the generation of anti-parasitic $C D 4^{+} \mathrm{T}$ cell responses that can protect mice from $\mathrm{CD}^{+} \mathrm{T}$ cell-mediated severe disease. The small red circles represent protozoan parasites and associated antigens.
Both lipoxin A4 and glucocorticoids have also been identified as important regulators of Th1 cell responses in mice infected with T. gondii (110-112). Lipoxin A4 is an eicosanoid mediator capable of suppressing DC IL-12 production in response to parasite antigen in vitro (110) or during T. gondii infection in mice (111). In this latter study, infection of mice lacking lipoxin A4 resulted in a fatal, parasite-induced inflammation (characterized by a potent Th1 cell response), but reduced parasite loads. Importantly, results from this and previous studies (113), suggest that IL-10 was critical for regulating inflammation during the acute stage of infection, while lipoxin A4 was important for immune regulation during chronic infection (111). A novel, IL-10-independent pathway of immune regulation was also recently identified in this infection model, whereby glucocorticoids produced by the hypothalamicpituitary-adrenal axis during $T$. gondii infection act directly on $\mathrm{CD} 4{ }^{+} \mathrm{T}$ cells to prevent Th1 cell hyperresponsiveness and resulting pathology (112). Given the critical roles for both IL-10-dependent and IL-10-independent pathways in preventing inflammatory diseases associated with protozoan infections, temporal and/or transient blockade of one or the other pathways may be a viable way to enable sufficient pro-inflammatory immunity to control parasite growth, but also leave enough regulatory machinery in place to prevent disease.

\section{CONCLUDING REMARIS}

There are currently no vaccines to protect against or treat diseases caused by protozoan parasites. It has proven extremely difficult to generate robust and long-lasting $\mathrm{CD} 4{ }^{+} \mathrm{T}$ cell responses against the responsible pathogens (3). An important impediment for generating sufficient immunity against these pathogens could, in some cases, be the accompanying regulatory immune response that aims to limit inflammation. Treg cell depletion can dramatically improve candidate malaria vaccine efficacy $(114,115)$, although as mentioned above, these studies must be interpreted with caution because of the use of anti-CD25 mAb for Treg cell modulation. Nevertheless, the blockade of IL-10 produced by antigen-specific Th1 cells improved anti-parasitic immunity generated by a candidate vaccine directed against $L$. major (116), while studies on T. gondii indicated that induction of IL-10-producing Th1 cells following vaccination caused a lethal infection upon secondary exposure to the parasite (117). Although the depletion of Treg cells and/or IL-10-producing Th1 cells is not a viable option for improving vaccine efficacy given the critical roles of these cells in preventing immune-mediated disease, a much better understanding about how regulatory immune responses can be locally and temporarily modulated to enhance vaccine-induced immune responses may be of significant benefit.

The regulation of Th1 cell responses during protozoan infections is clearly important to ensure both sufficient generation of inflammatory mediators to control parasite growth, as well as to prevent excessive production of these molecules in sensitive tissue sites. IL-10 has emerged as an important regulator of these responses, both produced in a highly regulated manner by Th1 cells themselves, as well as parasite-activated innate immune cells. However, IL-10 is not alone in this activity, and alternative mechanisms of Th1 cell regulation have been identified. Our challenge remains to fully define these mechanisms of Th1 cell regulation and to use this knowledge to improve therapeutic options and vaccine efficacy. Research in protozoan infections of both mice and humans is ideally placed to identify broad mechanisms of immune 
regulation that are relevant not only to parasitic infections but also for autoimmune and physiological diseases, as well as cancer.

\section{AUTHOR CONTRIBUTIONS}

Christian R. Engwerda, Susanna S. Ng, and Patrick T. Bunn all contributed to the planning and research in this paper. Susanna $\mathrm{S}$. Ng conceived and produced both figures, while Christian R. Engwerda and Patrick T. Bunn wrote the paper.

\section{ACKNOWLEDGMENTS}

We thank members of the Engwerda Laboratory at QIMR Berghofer for assistance with researching this paper and for helpful discussions.

\section{REFERENCES}

1. Janeway CA Jr, Medzhitov R. Innate immune recognition. Annu Rev Immunol (2002) 20:197-216. doi:10.1146/annurev.immunol.20.083001.084359

2. Banchereau J, Briere F, Caux C, Davoust J, Lebecque S, Liu YJ, et al. Immunobiology of dendritic cells. Annu Rev Immunol (2000) 18:767-811. doi:10.1146/ annurev.immunol.18.1.767

3. Sacks DL. Vaccines against tropical parasitic diseases: a persisting answer to a persisting problem. Nat Immunol (2014) 15:403-5. doi:10.1038/ni.2853

4. Sakaguchi S, Yamaguchi T, Nomura T, Ono M. Regulatory T cells and immune tolerance. Cell (2008) 133:775-87. doi:10.1016/j.cell.2008.05.009

5. Mellor AL, Munn DH. IDO expression by dendritic cells: tolerance and tryptophan catabolism. Nat Rev Immunol (2004) 4:762-74. doi:10.1038/nri1457

6. Munn DH, Sharma MD, Baban B, Harding HP, Zhang Y, Ron D, et al. GCN2 kinase in $\mathrm{T}$ cells mediates proliferative arrest and anergy induction in response to indoleamine 2,3-dioxygenase. Immunity (2005) 22:633-42. doi:10.1016/j.immuni.2005.03.013

7. Fallarino F, Grohmann U, Vacca C, Orabona C, Spreca A, Fioretti MC, et al. T cell apoptosis by kynurenines. Adv Exp Med Biol (2003) 527:183-90. doi:10.1007/978-1-4615-0135-0_21

8. Boonstra A, Rajsbaum R, Holman M, Marques R, Asselin-Paturel C, Pereira JP, et al. Macrophages and myeloid dendritic cells, but not plasmacytoid dendritic cells, produce IL-10 in response to MyD88- and TRIF-dependent TLR signals, and TLR-independent signals. J Immunol (2006) 177:7551-8. doi:10.4049/jimmunol.177.11.7551

9. Kehrl JH, Wakefield LM, Roberts AB, Jakowlew S, Alvarez-Mon M, Derynck R, et al. Production of transforming growth factor beta by human T lymphocytes and its potential role in the regulation of T cell growth. J Exp Med (1986) 163:1037-50. doi:10.1084/jem.163.5.1037

10. Shull MM, Ormsby I, Kier AB, Pawlowski S, Diebold RJ, Yin M, et al. Targeted disruption of the mouse transforming growth factor-beta 1 gene results in multifocal inflammatory disease. Nature (1992) 359:693-9. doi:10.1038/ 359693a0

11. Mizoguchi A, Mizoguchi E, Takedatsu H, Blumberg RS, Bhan AK. Chronic intestinal inflammatory condition generates IL-10-producing regulatory $\mathrm{B}$ cell subset characterized by CD1d upregulation. Immunity (2002) 16:219-30. doi:10.1016/S1074-7613(02)00274-1

12. Owens BM, Beattie L, Moore JW, Brown N, Mann JL, Dalton JE, et al. IL-10producing Th1 cells and disease progression are regulated by distinct CD11c(+) cell populations during visceral leishmaniasis. PLoS Pathog (2012) 8:e1002827. doi:10.1371/journal.ppat.1002827

13. Svensson M, Maroof A, Ato M, Kaye PM. Stromal cells direct local differentiation of regulatory dendritic cells. Immunity (2004) 21:805-16. doi:10.1016/j. immuni.2004.10.012

14. Wong KA, Rodriguez A. Plasmodium infection and endotoxic shock induce the expansion of regulatory dendritic cells. J Immunol (2008) 180:716-26. doi:10.4049/jimmunol.180.2.716

15. Sheel M, Engwerda CR. The diverse roles of monocytes in inflammation caused by protozoan parasitic diseases. Trends Parasitol (2012) 28:408-16. doi:10.1016/j.pt.2012.07.008

16. Van Dyken SJ, Locksley RM. Interleukin-4- and interleukin-13-mediated alternatively activated macrophages: roles in homeostasis and disease. Annu Rev Immunol (2013) 31:317-43. doi:10.1146/annurev-immunol-032712-095906
17. Leon B, Lopez-Bravo M, Ardavin C. Monocyte-derived dendritic cells formed at the infection site control the induction of protective $\mathrm{T}$ helper 1 responses against Leishmania. Immunity (2007) 26:519-31. doi:10.1016/j.immuni.2007. 01.017

18. Sato N, Kuziel WA, Melby PC, Reddick RL, Kostecki V, Zhao W, et al. Defects in the generation of IFN-gamma are overcome to control infection with Leishmania donovani in CC chemokine receptor (CCR) 5-, macrophage inflammatory protein-1 alpha-, or CCR2-deficient mice. J Immunol (1999) 163:5519-25.

19. Bosschaerts T, Guilliams M, Stijlemans B, Morias Y, Engel D, Tacke F, et al. Tip-DC development during parasitic infection is regulated by IL-10 and requires CCL2/CCR2, IFN-gamma and MyD88 signaling. PLoS Pathog (2010) 6:e1001045. doi:10.1371/journal.ppat.1001045

20. Guilliams M, Movahedi K, Bosschaerts T, VandenDriessche T, Chuah MK, Herin M, et al. IL-10 dampens TNF/inducible nitric oxide synthase-producing dendritic cell-mediated pathogenicity during parasitic infection. J Immunol (2009) 182:1107-18. doi:10.4049/jimmunol.182.2.1107

21. Modolell M, Choi BS, Ryan RO, Hancock M, Titus RG, Abebe T, et al. Local suppression of $\mathrm{T}$ cell responses by arginase-induced $\mathrm{L}$-arginine depletion in nonhealing leishmaniasis. PLoS Negl Trop Dis (2009) 3:e480. doi:10.1371/journal. pntd.0000480

22. El Kasmi KC, Qualls JE, Pesce JT, Smith AM, Thompson RW, Henao-Tamayo $\mathrm{M}$, et al. Toll-like receptor-induced arginase 1 in macrophages thwarts effective immunity against intracellular pathogens. Nat Immunol (2008) 9:1399-406. doi:10.1038/ni.1671

23. Sakaguchi S, Sakaguchi N, Asano M, Itoh M, Toda M. Immunologic selftolerance maintained by activated $\mathrm{T}$ cells expressing IL-2 receptor alpha-chains (CD25). Breakdown of a single mechanism of self-tolerance causes various autoimmune diseases. J Immunol (1995) 155:1151-64.

24. Shevach EM, DiPaolo RA, Andersson J, Zhao DM, Stephens GL, Thornton AM. The lifestyle of naturally occurring CD4+ CD25+ Foxp3+ regulatory T cells. Immunol Rev (2006) 212:60-73. doi:10.1111/j.0105-2896.2006.00415.x

25. O'Garra A, Vieira PL, Vieira P, Goldfeld AE. IL-10-producing and naturally occurring CD4+ Tregs: limiting collateral damage. J Clin Invest (2004) 114:1372-8. doi:10.1172/JCI200423215

26. Chen Y, Kuchroo VK, Inobe J, Hafler DA, Weiner HL. Regulatory T cell clones induced by oral tolerance: suppression of autoimmune encephalomyelitis. Science (1994) 265:1237-40. doi:10.1126/science.7520605

27. Chen W, Jin W, Hardegen N, Lei KJ, Li L, Marinos N, et al. Conversion of peripheral CD4+CD25- naive T cells to CD4+CD25+ regulatory T cells by TGFbeta induction of transcription factor Foxp3. J Exp Med (2003) 198:1875-86. doi:10.1084/jem.20030152

28. Belkaid Y. Regulatory T cells and infection: a dangerous necessity. Nat Rev Immunol (2007) 7:875-88. doi:10.1038/nri2189

29. Pandiyan P, Zheng L, Ishihara S, Reed J, Lenardo MJ. CD4+CD25+Foxp3+ regulatory $\mathrm{T}$ cells induce cytokine deprivation-mediated apoptosis of effector CD4+ T cells. Nat Immunol (2007) 8:1353-62. doi:10.1038/ni1536

30. Chaudhry A, Rudra D, Treuting P, Samstein RM, Liang Y, Kas A, et al. CD4+ regulatory T cells control TH17 responses in a Stat3-dependent manner. Science (2009) 326:986-91. doi:10.1126/science.1172702

31. Koch MA, Tucker-Heard G, Perdue NR, Killebrew JR, Urdahl KB, Campbell DJ. The transcription factor T-bet controls regulatory $\mathrm{T}$ cell homeostasis and function during type 1 inflammation. Nat Immunol (2009) 10:595-602. doi:10.1038/ni.1731

32. Linterman MA, Pierson W, Lee SK, Kallies A, Kawamoto S, Rayner TF, et al. Foxp3+ follicular regulatory $\mathrm{T}$ cells control the germinal center response. Nat Med (2011) 17:975-82. doi:10.1038/nm.2425

33. Zheng Y, Chaudhry A, Kas A, deRoos P, Kim JM, Chu TT, et al. Regulatory T-cell suppressor program co-opts transcription factor IRF4 to control T(H)2 responses. Nature (2009) 458:351-6. doi:10.1038/nature07674

34. Liston A, Gray DH. Homeostatic control of regulatory T cell diversity. Nat Rev Immunol (2014) 14:154-65. doi:10.1038/nri3605

35. Hall AO, Beiting DP, Tato C, John B, Oldenhove G, Lombana CG, et al. The cytokines interleukin 27 and interferon-gamma promote distinct Treg cell populations required to limit infection-induced pathology. Immunity (2012) 37:511-23. doi:10.1016/j.immuni.2012.06.014

36. Belkaid Y, Piccirillo CA, Mendez S, Shevach EM, Sacks DL. CD4+CD25+ regulatory $\mathrm{T}$ cells control Leishmania major persistence and immunity. Nature (2002) 420:502-7. doi:10.1038/nature01152 
37. Suffia IJ, Reckling SK, Piccirillo CA, Goldszmid RS, Belkaid Y. Infected siterestricted Foxp3+ natural regulatory $\mathrm{T}$ cells are specific for microbial antigens. J Exp Med (2006) 203:777-88. doi:10.1084/jem.20052056

38. Hisaeda H, Maekawa Y, Iwakawa D, Okada H, Himeno K, Kishihara K, et al. Escape of malaria parasites from host immunity requires CD4+ CD25+ regulatory T cells. Nat Med (2004) 10:29-30. doi:10.1038/nm975

39. Walther M, Tongren JE, Andrews L, Korbel D, King E, Fletcher H, et al. Upregulation of TGF-beta, FOXP3, and CD4+CD25+ regulatory T cells correlates with more rapid parasite growth in human malaria infection. Immunity (2005) 23:287-96. doi:10.1016/j.immuni.2005.08.006

40. Couper KN, Blount DG, de Souza JB, Suffia I, Belkaid Y, Riley EM. Incomplete depletion and rapid regeneration of Foxp3+ regulatory $\mathrm{T}$ cells following anti-CD25 treatment in malaria-infected mice. J Immunol (2007) 178:4136-46. doi:10.4049/jimmunol.178.7.4136

41. Amante FH, Stanley AC, Randall LM, Zhou Y, Haque A, McSweeney K, et al. A role for natural regulatory $\mathrm{T}$ cells in the pathogenesis of experimental cerebral malaria. Am J Pathol (2007) 171:548-59. doi:10.2353/ajpath.2007.061033

42. Nie CQ, Bernard NJ, Schofield L, Hansen DS. CD4+ CD25+ regulatory T cells suppress CD4+ T-cell function and inhibit the development of Plasmodium berghei-specific TH1 responses involved in cerebral malaria pathogenesis. Infect Immun (2007) 75:2275-82. doi:10.1128/IAI.01783-06

43. Vigario AM, Gorgette O, Dujardin HC, Cruz T, Cazenave PA, Six A, et al. Regulatory CD4+ CD25+ Foxp3+ T cells expand during experimental Plasmodium infection but do not prevent cerebral malaria. Int J Parasitol (2007) 37:963-73. doi:10.1016/j.ijpara.2007.01.004

44. Lahl K, Loddenkemper C, Drouin C, Freyer J, Arnason J, Eberl G, et al. Selective depletion of Foxp3+ regulatory T cells induces a scurfy-like disease. J Exp Med (2007) 204:57-63. doi:10.1084/jem.20061852

45. Haque A, Best SE, Amante FH, Mustafah S, Desbarrieres L, de Labastida F, et al. CD4+ natural regulatory $\mathrm{T}$ cells prevent experimental cerebral malaria via CTLA-4 when expanded in vivo. PLoS Pathog (2010) 6:e1001221. doi:10. 1371/journal.ppat.1001221

46. Steeg C, Adler G, Sparwasser T, Fleischer B, Jacobs T. Limited role of CD4+Foxp3+ regulatory $\mathrm{T}$ cells in the control of experimental cerebral malaria. J Immunol (2009) 183:7014-22. doi:10.4049/jimmunol.0901422

47. O'Garra A, Vieira P. T(H)1 cells control themselves by producing interleukin10. Nat Rev Immunol (2007) 7:425-8. doi:10.1038/nri2097

48. Saraiva M, O'Garra A. The regulation of IL-10 production by immune cells. Nat Rev Immunol (2010) 10:170-81. doi:10.1038/nri2711

49. Fiorentino DF, Bond MW, Mosmann TR. Two types of mouse T helper cell. IV. Th2 clones secrete a factor that inhibits cytokine production by Th1 clones. J Exp Med (1989) 170:2081-95. doi:10.1084/jem.170.6.2081

50. Meyaard L, Hovenkamp E, Otto SA, Miedema F. IL-12-induced IL-10 production by human $\mathrm{T}$ cells as a negative feedback for IL-12-induced immune responses. J Immunol (1996) 156:2776-82.

51. Yssel H, De Waal Malefyt R, Roncarolo MG, Abrams JS, Lahesmaa R, Spits H, et al. IL-10 is produced by subsets of human CD4+ T cell clones and peripheral blood T cells. J Immunol (1992) 149:2378-84.

52. Groux H, O'Garra A, Bigler M, Rouleau M, Antonenko S, de Vries JE, et al. A CD4+ T-cell subset inhibits antigen-specific T-cell responses and prevents colitis. Nature (1997) 389:737-42. doi:10.1038/39614

53. Stumhofer JS, Silver JS, Laurence A, Porrett PM, Harris TH, Turka LA, et al. Interleukins 27 and 6 induce STAT3-mediated T cell production of interleukin 10. Nat Immunol (2007) 8:1363-71. doi:10.1038/ni1537

54. Jankovic D, Kullberg MC, Feng CG, Goldszmid RS, Collazo CM, Wilson M, et al. Conventional T-bet(+)Foxp3(-) Th1 cells are the major source of hostprotective regulatory IL-10 during intracellular protozoan infection. J Exp Med (2007) 204:273-83. doi:10.1084/jem.20062175

55. Anderson CF, Oukka M, Kuchroo VJ, Sacks D. CD4(+)CD25(-)Foxp3(-) Th1 cells are the source of IL-10-mediated immune suppression in chronic cutaneous leishmaniasis. J Exp Med (2007) 204:285-97. doi:10.1084/jem.20061886

56. Wilson EH, Wille-Reece U, Dzierszinski F, Hunter CA. A critical role for IL10 in limiting inflammation during toxoplasmic encephalitis. J Neuroimmunol (2005) 165:63-74. doi:10.1016/j.jneuroim.2005.04.018

57. Couper KN, Blount DG, Wilson MS, Hafalla JC, Belkaid Y, Kamanaka M, et al. IL-10 from CD4CD25Foxp3CD127 adaptive regulatory T cells modulates parasite clearance and pathology during malaria infection. PLoS Pathog (2008) 4:e1000004. doi:10.1371/journal.ppat.1000004
58. do Rosario AP, Lamb T, Spence P, Stephens R, Lang A, Roers A, et al. IL-27 promotes IL-10 production by effector Th1 CD4+ T cells: a critical mechanism for protection from severe immunopathology during malaria infection. J Immunol (2012) 188:1178-90. doi:10.4049/jimmunol.1102755

59. Reed SG, Brownell CE, Russo DM, Silva JS, Grabstein KH, Morrissey PJ. IL10 mediates susceptibility to Trypanosoma cruzi infection. J Immunol (1994) 153:3135-40.

60. Roffe E, Rothfuchs AG, Santiago HC, Marino AP, Ribeiro-Gomes FL, Eckhaus $\mathrm{M}$, et al. IL-10 limits parasite burden and protects against fatal myocarditis in a mouse model of Trypanosoma cruzi infection. J Immunol (2012) 188:649-60. doi:10.4049/jimmunol.1003845

61. Namangala B, Noel W, De Baetselier P, Brys L, Beschin A. Relative contribution of interferon-gamma and interleukin-10 to resistance to murine African trypanosomosis. J Infect Dis (2001) 183:1794-800. doi:10.1086/320731

62. Nylen S, Maurya R, Eidsmo L, Manandhar KD, Sundar S, Sacks D. Splenic accumulation of IL-10 mRNA in T cells distinct from CD4+CD25+ (Foxp3) regulatory T cells in human visceral leishmaniasis. J Exp Med (2007) 204:805-17. doi:10.1084/jem.20061141

63. Jagannathan P, Eccles-James I, Bowen K, Nankya F, Auma A, Wamala S, et al. IFNgamma/IL-10 co-producing cells dominate the CD4 response to malaria in highly exposed children. PLoS Pathog (2014) 10:e1003864. doi:10.1371/ journal.ppat.1003864

64. Portugal S, Moebius J, Skinner J, Doumbo S, Doumtabe D, Kone Y, et al. Exposure-dependent control of malaria-induced inflammation in children. PLoS Pathog (2014) 10:e1004079. doi:10.1371/journal.ppat.1004079

65. Gautam S, Kumar R, Maurya R, Nylen S, Ansari N, Rai M, et al. IL-10 neutralization promotes parasite clearance in splenic aspirate cells from patients with visceral leishmaniasis. J Infect Dis (2011) 204:1134-7. doi:10. 1093/infdis/jir461

66. Brustoski K, Moller U, Kramer M, Petelski A, Brenner S, Palmer DR, et al. IFN-gamma and IL-10 mediate parasite-specific immune responses of cord blood cells induced by pregnancy-associated Plasmodium falciparum malaria. J Immunol (2005) 174:1738-45. doi:10.4049/jimmunol.174.3.1738

67. Walther M, Jeffries D, Finney OC, Njie M, Ebonyi A, Deininger S, et al. Distinct roles for FOXP3 and FOXP3 CD4 T cells in regulating cellular immunity to uncomplicated and severe Plasmodium falciparum malaria. PLoS Pathog (2009) 5:e1000364. doi:10.1371/journal.ppat.1000364

68. Moore KW, de Waal Malefyt R, Coffman RL, O'Garra A. Interleukin-10 and the interleukin-10 receptor. Annu Rev Immunol (2001) 19:683-765. doi:10.1146/annurev.immunol.19.1.683

69. Kuhn R, Lohler J, Rennick D, Rajewsky K, Muller W. Interleukin-10-deficient mice develop chronic enterocolitis. Cell (1993) 75:263-74. doi:10.1016/00928674(93)80068-P

70. Boussiotis VA, Tsai EY, Yunis EJ, Thim S, Delgado JC, Dascher CC, et al. IL-10producing $\mathrm{T}$ cells suppress immune responses in anergic tuberculosis patients. J Clin Invest (2000) 105:1317-25. doi:10.1172/JCI9918

71. Plebanski M, Flanagan KL, Lee EA, Reece WH, Hart K, Gelder C, et al. Interleukin 10-mediated immunosuppression by a variant CD4 $\mathrm{T}$ cell epitope of Plasmodium falciparum. Immunity (1999) 10:651-60. doi:10.1016/S10747613(00)80064-3

72. Ha SJ, West EE, Araki K, Smith KA, Ahmed R. Manipulating both the inhibitory and stimulatory immune system towards the success of therapeutic vaccination against chronic viral infections. Immunol Rev (2008) 223:317-33. doi:10.1111/j.1600-065X.2008.00638.x

73. Jin HT, Anderson AC, Tan WG, West EE, Ha SJ, Araki K, et al. Cooperation of Tim-3 and PD-1 in CD8 T-cell exhaustion during chronic viral infection. Proc Natl Acad Sci U S A (2010) 107:14733-8. doi:10.1073/pnas.1009731107

74. Camisaschi C, Casati C, Rini F, Perego M, De Filippo A, Triebel F, et al. LAG-3 expression defines a subset of CD4(+)CD25(high)Foxp3(+) regulatory $\mathrm{T}$ cells that are expanded at tumor sites. J Immunol (2010) 184:6545-51. doi:10.4049/jimmunol.0903879

75. Sing A, Rost D, Tvardovskaia N, Roggenkamp A, Wiedemann A, Kirschning CJ, et al. Yersinia V-antigen exploits toll-like receptor 2 and CD14 for interleukin 10-mediated immunosuppression. J Exp Med (2002) 196:1017-24. doi:10.1084/jem.20020908

76. Ouyang W, Rutz S, Crellin NK, Valdez PA, Hymowitz SG. Regulation and functions of the IL-10 family of cytokines in inflammation and disease. Annu Rev Immunol (2011) 29:71-109. doi:10.1146/annurev-immunol-031210-101312 
77. Awasthi A, Carrier Y, Peron JP, Bettelli E, Kamanaka M, Flavell RA, et al. A dominant function for interleukin 27 in generating interleukin 10producing anti-inflammatory T cells. Nat Immunol (2007) 8:1380-9. doi:10. 1038/nil541

78. Fitzgerald DC, Zhang GX, El-Behi M, Fonseca-Kelly Z, Li H, Yu S, et al. Suppression of autoimmune inflammation of the central nervous system by interleukin 10 secreted by interleukin 27-stimulated T cells. Nat Immunol (2007) 8:1372-9. doi:10.1038/ni1540

79. Yoshida H, Nakaya M, Miyazaki Y. Interleukin 27: a double-edged sword for offense and defense. J Leukoc Biol (2009) 86:1295-303. doi:10.1189/ jlb.0609445

80. Pot C, Jin H, Awasthi A, Liu SM, Lai CY, Madan R, et al. Cutting edge: IL-27 induces the transcription factor c-Maf, cytokine IL-21, and the costimulatory receptor ICOS that coordinately act together to promote differentiation of IL-10-producing Tr1 cells. J Immunol (2009) 183:797-801. doi:10.4049/jimmunol.0901233

81. Spolski R, Kim HP, Zhu W, Levy DE, Leonard WJ. IL-21 mediates suppressive effects via its induction of IL-10. J Immunol (2009) 182:2859-67. doi:10.4049/jimmunol.0802978

82. Pflanz S, Hibbert L, Mattson J, Rosales R, Vaisberg E, Bazan JF, et al. WSX-1 and glycoprotein 130 constitute a signal-transducing receptor for IL-27. J Immunol (2004) 172:2225-31. doi:10.4049/jimmunol.172.4.2225

83. Pflanz S, Timans JC, Cheung J, Rosales R, Kanzler H, Gilbert J, et al. IL-27, a heterodimeric cytokine composed of EBI3 and p28 protein, induces proliferation of naive CD4+ T cells. Immunity (2002) 16:779-90. doi:10.1016/S10747613(02)00324-2

84. Jones SA. Directing transition from innate to acquired immunity: defining a role for IL-6. J Immunol (2005) 175:3463-8. doi:10.4049/jimmunol.175.6.3463

85. Jones SA, Richards PJ, Scheller J, Rose-John S. IL-6 transsignaling: the in vivo consequences. J Interferon Cytokine Res (2005) 25:241-53. doi:10.1089/jir.2005. 25.241

86. Apetoh L, Quintana FJ, Pot C, Joller N, Xiao S, Kumar D, et al. The aryl hydrocarbon receptor interacts with c-Maf to promote the differentiation of type 1 regulatory T cells induced by IL-27. Nat Immunol (2010) 11:854-61. doi:10.1038/ni.1912

87. Xu J, Yang Y, Qiu G, Lal G, Wu Z, Levy DE, et al. c-Maf regulates IL10 expression during Th17 polarization. J Immunol (2009) 182:6226-36. doi:10.4049/jimmunol.0900123

88. Carrier Y, Whitters MJ, Miyashiro JS, LaBranche TP, Ramon HE, Benoit SE, et al. Enhanced GITR/GITRL interactions augment IL-27 expression and induce IL-10-producing Tr-1 like cells. Eur J Immunol (2012) 42:1393-404. doi:10.1002/eji.201142162

89. Stumhofer JS, Tait ED, Quinn WJ III, Hosken N, Spudy B, Goenka R, et al. A role for IL-27p28 as an antagonist of gp 130-mediated signaling. Nat Immunol (2010) 11:1119-26. doi:10.1038/ni.1957

90. Findlay EG, Greig R, Stumhofer JS, Hafalla JC, de Souza JB, Saris CJ, et al. Essential role for IL-27 receptor signaling in prevention of Th1-mediated immunopathology during malaria infection. J Immunol (2010) 185:2482-92. doi:10.4049/jimmunol.0904019

91. Anderson CF, Stumhofer JS, Hunter CA, Sacks D. IL-27 regulates IL-10 and IL-17 from CD4+ cells in nonhealing Leishmania major infection. J Immunol (2009) 183:4619-27. doi:10.4049/jimmunol.0804024

92. Ansari NA, Kumar R, Gautam S, Nylen S, Singh OP, Sundar S, et al. IL-27 and IL-21 are associated with T cell IL-10 responses in human visceral leishmaniasis. J Immunol (2011) 186:3977-85. doi:10.4049/jimmunol.1003588

93. Cretney E, Xin A, Shi W, Minnich M, Masson F, Miasari M, et al. The transcription factors Blimp-1 and IRF4 jointly control the differentiation and function of effector regulatory T cells. Nat Immunol (2011) 12:304-11. doi:10.1038/ni.2006

94. Iwasaki Y, Fujio K, Okamura T, Yanai A, Sumitomo S, Shoda H, et al. Egr-2 transcription factor is required for Blimp-1-mediated IL-10 production in IL-27-stimulated CD4+ T cells. Eur J Immunol (2013) 43:1063-73. doi:10.1002/eji.201242942

95. Neumann C, Heinrich F, Neumann K, Junghans V, Mashreghi MF, Ahlers J, et al. Role of Blimp-1 in programing Th effector cells into IL-10 producers. J Exp Med (2014) 211:1807-19. doi:10.1084/jem.20131548

96. Okamura T, Fujio K, Shibuya M, Sumitomo S, Shoda H, Sakaguchi S, et al. CD4+CD25-LAG3+ regulatory $\mathrm{T}$ cells controlled by the transcription factor
Egr-2. Proc Natl Acad Sci U S A (2009) 106:13974-9. doi:10.1073/pnas. 0906872106

97. Kassner N, Krueger M, Yagita H, Dzionek A, Hutloff A, Kroczek R, et al. Cutting edge: plasmacytoid dendritic cells induce IL-10 production in T cells via the delta-like-4/Notch axis. J Immunol (2010) 184:550-4. doi:10.4049/jimmunol. 0903152

98. Isaacs A, Lindenmann J. Virus interference. I. The interferon. Proc R Soc Lond B Biol Sci (1957) 147:258-67. doi:10.1098/rspb.1957.0049

99. Isaacs A, Lindenmann J, Valentine RC. Virus interference. II. Some properties of interferon. Proc R Soc Lond B Biol Sci (1957) 147:268-73. doi:10.1098/rspb. 1957.0049

100. Lopez R, Demick KP, Mansfield JM, Paulnock DM. Type I IFNs play a role in early resistance, but subsequent susceptibility, to the African trypanosomes. J Immunol (2008) 181:4908-17. doi:10.4049/jimmunol.181.7.4908

101. Chessler AD, Caradonna KL, Da'dara A, Burleigh BA. Type I interferons increase host susceptibility to Trypanosoma cruzi infection. Infect Immun (2011) 79:2112-9. doi:10.1128/IAI.01176-10

102. Liehl P, Zuzarte-Luis V, Chan J, Zillinger T, Baptista F, Carapau D, et al. Host-cell sensors for Plasmodium activate innate immunity against liver-stage infection. Nat Med (2014) 20:47-53. doi:10.1038/nm.3424

103. Haque A, Best SE, Ammerdorffer A, Desbarrieres L, de Oca MM, Amante FH, et al. Type I interferons suppress CD4(+) T-cell-dependent parasite control during blood-stage Plasmodium infection. Eur J Immunol (2011) 41:2688-98. doi:10.1002/eji.201141539

104. Sharma S, DeOliveira RB, Kalantari P, Parroche P, Goutagny N, Jiang Z, et al. Innate immune recognition of an AT-rich stem-loop DNA motif in the Plasmodium falciparum genome. Immunity (2011) 35:194-207. doi:10.1016/j. immuni.2011.05.016

105. Haque A, Best SE, Montes de Oca M, James KR, Ammerdorffer A, Edwards CL, et al. Type I IFN signaling in CD8- DCs impairs Th1-dependent malaria immunity. J Clin Invest (2014) 124:2483-96. doi:10.1172/JCI70698

106. Butler NS, Harris TH, Blader IJ. Regulation of immunopathogenesis during Plasmodium and Toxoplasma infections: more parallels than distinctions? Trends Parasitol (2013) 29:593-602. doi:10.1016/j.pt.2013.10.002

107. de Kossodo S, Grau GE. Profiles of cytokine production in relation with susceptibility to cerebral malaria. J Immunol (1993) 151:4811-20.

108. Buzoni-Gatel D, Debbabi H, Mennechet FJ, Martin V, Lepage AC, Schwartzman JD, et al. Murine ileitis after intracellular parasite infection is controlled by TGF-beta-producing intraepithelial lymphocytes. Gastroenterology (2001) 120:914-24. doi:10.1053/gast.2001.22432a

109. Li MO, Flavell RA. TGF-beta: a master of all T cell trades. Cell (2008) 134:392-404. doi:10.1016/j.cell.2008.07.025

110. Aliberti J, Hieny S, Reis e Sousa C, Serhan CN, Sher A. Lipoxin-mediated inhibition of IL-12 production by DCs: a mechanism for regulation of microbial immunity. Nat Immunol (2002) 3:76-82. doi:10.1038/ni745

111. Aliberti J, Serhan C, Sher A. Parasite-induced lipoxin A4 is an endogenous regulator of IL-12 production and immunopathology in Toxoplasma gondii infection. J Exp Med (2002) 196:1253-62. doi:10.1084/jem.20021183

112. Kugler DG, Mittelstadt PR, Ashwell JD, Sher A, Jankovic D. CD4+ T cells are trigger and target of the glucocorticoid response that prevents lethal immunopathology in toxoplasma infection. J Exp Med (2013) 210:1919-27. doi:10.1084/jem.20122300

113. Gazzinelli RT, Wysocka M, Hieny S, Scharton-Kersten T, Cheever A, Kuhn R, et al. In the absence of endogenous IL-10, mice acutely infected with Toxoplasma gondii succumb to a lethal immune response dependent on CD4+ T cells and accompanied by overproduction of IL-12, IFN-gamma and TNFalpha. J Immunol (1996) 157:798-805.

114. Amante FH, Haque A, Stanley AC, Rivera Fde L, Randall LM, Wilson YA, et al. Immune-mediated mechanisms of parasite tissue sequestration during experimental cerebral malaria. J Immunol (2010) 185:3632-42. doi:10.4049/ jimmunol.1000944

115. Moore AC, Gallimore A, Draper SJ, Watkins KR, Gilbert SC, Hill AV. AntiCD25 antibody enhancement of vaccine-induced immunogenicity: increased durable cellular immunity with reduced immunodominance. J Immunol (2005) 175:7264-73. doi:10.4049/jimmunol.175.11.7264

116. Stober CB, Lange UG, Roberts MT, Alcami A, Blackwell JM. IL-10 from regulatory $\mathrm{T}$ cells determines vaccine efficacy in murine Leishmania major infection. J Immunol (2005) 175:2517-24. doi:10.4049/jimmunol.175.4.2517 
117. Shaw MH, Freeman GJ, Scott MF, Fox BA, Bzik DJ, Belkaid Y, et al. Tyk2 negatively regulates adaptive Th1 immunity by mediating IL-10 signaling and promoting IFN-gamma-dependent IL-10 reactivation. J Immunol (2006) 176:7263-71. doi:10.4049/jimmunol.176.12.7263

Conflict of Interest Statement: The authors declare that the research was conducted in the absence of any commercial or financial relationships that could be construed as a potential conflict of interest.

Received: 05 August 2014; paper pending published: 08 September 2014; accepted: 25 September 2014; published online: 13 October 2014.
Citation: Engwerda CR, $\mathrm{Ng}$ SS and Bunn PT (2014) The regulation of $\mathrm{CD}^{+} \mathrm{T}$ cell responses during protozoan infections. Front. Immunol. 5:498. doi: 10.3389/fimmu.2014.00498

This article was submitted to T Cell Biology, a section of the journal Frontiers in Immunology.

Copyright (c) 2014 Engwerda, $\mathrm{Ng}$ and Bunn. This is an open-access article distributed under the terms of the Creative Commons Attribution License (CC BY). The use, distribution or reproduction in other forums is permitted, provided the original author(s) or licensor are credited and that the original publication in this journal is cited, in accordance with accepted academic practice. No use, distribution or reproduction is permitted which does not comply with these terms. 